\title{
De NVMO is 35 geworden: een terugblik op haar adolescentie en moederschap
}

\author{
Lennart Bouman
}

Er is in de kolommen van dit lezenswaardige blad al menige pagina gewijd geweest aan de wordingsgeschiedenis van de NVMO. De animo voor mij om dit te schrijven en voor $\mathrm{u}$ om dit te lezen kan alleen voortkomen uit het feit dat ik inmiddels binnen de gelederen van dit gezelschap zeer oud ben en u hopelijk piepjong. Want alleen in dat geval gaat $u$ wellicht iets lezen dat $u$ nog niet wist; voor de anderen, de mij beter bekende lezers met al een verleden in de vereniging, is er alleen de spanning of ik dat verleden wel juist weergeef. En dat zal maar tot op zekere hoogte zo zijn, vrees ik.

Ik heb als voorzitter ongeveer een derde van de levensloop van onze dierbare dochter NVMO mogen begeleiden. Ik trad in deze functie aan toen zij aarzelend aan haar puberteit was begonnen en ik bleef haar voogd tot zij de volwassenheid was ingegaan, dus waarachtig wel iets om nog even bij stil te staan. Want zoals het een interessante vrouw betaamt was haar puberteit stormachtig en haar adolescentie er een van 'trial and error', met veel al of niet geslaagde vriendjes en korte of lange relaties die het toch niet bleken te zijn. Nu stop ik even met deze metafoor, want wellicht gaat deze of gene zich dit persoonlijk aantrekken, en keer ik terug tot de harde feiten uit de tachtiger en negentiger jaren van de vorige eeuw.

De vereniging werd in $1972^{1}$ opgericht als een onderonsje van en voor bij het onderwijs in de geneeskunde betrokken medici. Bij hen groeide in meer of mindere mate het besef dat het vermogen om tot een geslaagde opzet en uitvoering van het onderwijs te kunnen komen niet noodzakelijkerwijs tot de congenitale verworvenheden van de mens behoorde, iets wat in die tijd vreemd

Lennart Bouman $(\bowtie)$

Prof. dr. L.N. Bouman is oud-voorzitter NVMO, emeritus hoogleraar Fysiologie, AMC-UvA. genoeg wel de gangbare opinie was onder de meeste onderwijsgevenden in de geneeskunde. De bijeenkomsten van het gezelschap hielden het midden tussen een werkbespreking en een familiereünie waar men elkaar graag vertelde wat er in de afgelopen periode was gedaan en beleefd. Zij werden enkele keren per jaar in een van de universiteitssteden gehouden en er waren zowel dagen met vrije voordrachten als studiedagen gewijd aan een bepaald onderwijskundig thema. Het rommelde toen al behoorlijk in de faculteiten; Maastricht had al een compleet probleemgeoriënteerd curriculum, in Nijmegen was een blokprogramma operationeel en in Amsterdam (UvA) was hetzelfde gaande. Steeds meer werd duidelijk dat medische onderwijskunde een wetenschap op zich is, met specifieke vraagstellingen, een eigen methodiek en een eigen discussie. En eigen specialisten, voor een deel onderwijskundigen 'pur sang', maar meer nog bijgeschoolde medici die zich met hart en ziel tot dit nieuwe specialisme hadden bekeerd. Toch bleef de sfeer van goedwillend amateurisme nog lang hangen en erg vond ik dat niet. Wie kort na elkaar eerst een congres uit een der klassieke specialismen mocht bijwonen, in mijn geval was dat fysiologie of cardiologie, en daarna bijvoorbeeld een congres van de Europese organisatie voor medisch onderwijs, de AMEE, kon zich verbazen en verheugen over het totale verschil in sfeer en doel- stelling. Aan het klassieke congres neemt men deel om te scoren; bij het AMEE-congres komt men om met anderen te praten over het waarom en hoe van het onderwijs. Tenminste zo was het toen; wie wil weten of dat nog zo is moet maar eens gaan kijken.

Zowel door de aard van de problematiek als door de intocht van steeds meer echte onderwijskundigen kon een professionalisering van de vereniging niet uitblijven: mevrouw werd volwassen en sloeg haar moederlijke 
vleugels uit. Haar meest bekende kind, het inmiddels ook al bijna volwassen Gezond Onderwijs Congres (GOC), nu met de naam NVMO-congres, werd met de nodige barensweeën geboren ondanks de langdurige voorbereidende gymnastiekoefeningen, die overigens meer door de vader Albert Scherpbier dan door de moeder zelf werden uitgevoerd. Het bestuur was niet onverdeeld gelukkig met het plan, vooral niet omdat men voorzag dat dit het einde van de studiedagen zou betekenen. Dat het groepje verenigingsleden die met dit voorstel kwamen zich van de werknaam NVMOORD ${ }^{2}$ hadden voorzien hielp daarbij niet erg. Men vond elkaar weer (zoals immer in het NVMO-bestuur) in een mooi compromis: er zou een proefcongres worden gehouden in het statige Oud-Poelgeest en dan zou men zien of er leven in het plan zat. De tegenstanders verwachtten wellicht dat als dit flopte het gevaar wel geweken zou zijn. Het tegendeel bleek echter het geval en in 1991 vond het eerste officiële GOC plaats; de studiedagen zijn in de jaren daarna door een steeds slinkende belangstelling inderdaad verdwenen.

Onder de vleugels van moeder NVMO hebben zich in die tijd enkele adoptiekinderen ontwikkeld, met de familienaam 'werkgroepen', die uit het zicht van de buitenwereld uitgroeiden van een op eigen initiatief gevormde clubje geestverwanten tot productieve organisaties binnen de NVMO. De dochters 'vaardigheidsonderwijs' en 'computerondersteund onderwijs' helpen moeder ook nu nog veelvuldig in de zaak.

De enorme ontwikkeling in het medisch onderwijs in het laatste kwart van de vorige eeuw ${ }^{3}$ deed steeds meer docenten beseffen dat hun medische opleiding hen onvoldoende had toegerust om op een optimale wijze aan de verwachtingen van de studenten te kunnen beantwoorden. En voor zover deze notie niet uit eigen oordeel voortkwam werd deze wel opgedrongen door de evaluaties van de kwaliteit van het onderwijs die inmiddels algemeen ingang hadden gevonden. Om aan de behoefte aan docententraining te voldoen ging NVMO een kortstondig huwelijk aan met DMW, de koepel van de medische faculteiten in ons land in de stichting ODOS voor de onderwijskundige scholing van docenten. Tot dan toe hadden de kersverse echtelieden elkaar meer bestreden dan geliefd, omdat het creatieve kritische karakter van NVMO vaak had gebotst met de behoudende aard van haar nieuwe echtgenoot. Inmiddels is NVMO weer alleen maar nog steeds draagt zij bij aan de professionalisering van het medische docentencorps.
De moeilijkste maar uiteindelijk meest succesvolle telg van het NVMO-gezin werd veel te vroeg geboren, toen NVMO nog verre van volwassen was. Hij kreeg als koosnaam Bulletin Medisch Onderwijs mee, kortweg BMO, en diende om binnen de NVMO ontwikkelingen in het medisch onderwijs aan de leden bekend te maken. Het krantje had aanvankelijk niet méér grandeur dan dat van een mededelingenblad van een sportvereniging of een kerkgenootschap. Maar ook deze telg kwam in zijn puberteit toen het onderzoek naar de onderwijskundige aspecten van het medisch onderwijs groeide en de publicaties in het Bulletin op een steeds hoger niveau kwamen te staan. Toch had moeder NVMO grote moeite om haar geliefde telg te laten gaan. Hoe hij ook soebatte om niet meer bij zijn koosnaam genoemd te worden maar met zijn echte naam TMO, Tijdschrift voor Medisch Onderwijs, zij hield hem steevast voor dat hij daar nog niet groot genoeg voor was. Uiteindelijk moest zij hem in januari 2000 laten gaan ${ }^{4}$ maar TMO blijft graag nog altijd zijn moeder betrekken bij de grootse plannen die hij tot ontwikkeling wil brengen.

Maar hoe zit het met haar eigen moeder? Heeft zij die ooit gekend en heeft zij daar nu nog contact mee? Natuurlijk, zoals de meeste NVMO-leden wel weten. Moeder Marijke Sterman was erbij vanaf het eerste uur en heeft haar dochter nooit uit het oog verloren, ook niet toen zij zelf door ziekte een tijd uit de roulatie raakte. Nog dagelijks geniet NVMO van haar wijsheid, ervaring en goede zorg en ook de kinderen komen graag bij Oma langs met vragen en verhalen. Het is een gelukkige familie, en ik wens de NVMO, haar moeder en haar vele kinderen en kleinkinderen nog vele jaren van gelukkig samenzijn toe.

\section{Literatuur}

Bouman LN, van Rossum HJM. Een terugblik op 25 jaar NVMO. Bulletin Medisch Onderwijs 1997;16:48-53.

Bulte JA, Scherpbier AJJA. Prof. dr. Jaap Metz met emeritaat; een loopbaan verbonden met de Nederlandse Vereniging voor Medisch Onderwijs. Tijdschrift voor Medisch Onderwijs 2004;23:260-5.

Metz JCM, Bouman LN. Artikelenreeks over actuele ontwikkelingen in het medisch onderwijs. Ned Tijdschr Geesk 1994; 138:1014-7.

Redactie TMO, Van Bulletin naar Tijdschrift. Tijdschrift voor Medisch Onderwijs 2000;19:2-5. 